\title{
Effect of Tantalum Additions on the Properties of New High Magnetic Permeability Alloys "Nimalloy" in the Nickel and Manganese System*
}

\author{
By Hakaru Masumoto**, Yûetsu Murakami** \\ and Masakatsu Hinai**
}

\begin{abstract}
Masumoto et al. have previously discovered that alloys in composition near to $\mathrm{Ni}_{3} \mathrm{Mn}$ exhibited a high permeability when developed to an optimum degree of order, and these alloys were named Nimalloy. In the subsequent work on the effect of various additives on the properties of Ni-Mn alloys, the highest initial permeability of 121000 and the highest maximum permeability of 643000 have been obtained with $\mathrm{Ni}-\mathrm{Mn}-\mathrm{Fe}-\mathrm{Cr}-\mathrm{Mo}$ alloys.

The results of $\mathrm{Ta}$ additions to $\mathrm{Ni}-\mathrm{Mn}$ alloys show that with increasing Ta content, the permeability of $\mathrm{Ni}-\mathrm{Mn}$ alloys at first increases gradually, goes through a maximum rapidly, and then decreases gradually. The highest initial permeability of 20470 is obtained on the alloy composed of $75.88 \% \mathrm{Ni}, 19.47 \% \mathrm{Mn}$ and $4.65 \% \mathrm{Ta}$ when cooled at a rate of $240^{\circ} \mathrm{C} / \mathrm{hr}$ from $900^{\circ} \mathrm{C}$ and baked at $440^{\circ} \mathrm{C}$ for $64 \mathrm{hr}$, and the highest maximum permeability of 84800 on the alloy of $75.37 \%$ $\mathrm{Ni}, 19.08 \% \mathrm{Mn}$ and $5.55 \% \mathrm{Ta}$ when cooled at a rate of $240^{\circ} \mathrm{C} / \mathrm{hr}$ from $900^{\circ} \mathrm{C}$ and baked at $440^{\circ} \mathrm{C}$ for $65 \mathrm{hr}$. The latter alloy shows a coercive force of $0.0253 \mathrm{Oe}$ and a magnetic hysteresis loss of $50.85 \mathrm{erg} / \mathrm{cm}^{3} / \mathrm{cycle}$ for the maximum magnetic induction of $5000 \mathrm{G}$, and its electrical resistivity being $52.7 \mu \Omega-\mathrm{cm}$ at $20^{\circ} \mathrm{C}$.
\end{abstract}

(Received August 26, 1970)

\section{Introduction}

It has previously been found by Masumoto et al. ${ }^{(1)}$ that the ferromagnetic superlattice structure $\mathrm{Ni}_{3} \mathrm{Mn}$ in the $\mathrm{Ni}-\mathrm{Mn}$ system exhibits a high magnetic permeability when it is in an appropriate degree of order, and the high permeability $\mathrm{Ni}-\mathrm{Mn}$ alloys have been named Nimalloy. Following this discovery, the variation of Nimalloy characteristics were investigated with the addition of $\mathrm{Fe}^{(2)}, \mathrm{V}^{(3)}, \mathrm{Si}^{(4)}, \mathrm{Ti}^{(5)}, \mathrm{Al}^{(6)}, \mathrm{Sb}^{(7)}, \mathrm{Sn}^{(8)}$, $\mathrm{Cr}^{(9)}, \mathrm{W}^{(10)}, \mathrm{Ge}^{(11)}, \mathrm{Mo}^{(12)}, \mathrm{Co}^{(13)}, \mathrm{Cu}^{(13)}, \mathrm{Nb}^{(14)}$ and $\mathrm{Ta}^{(15)}$ to the $\mathrm{Ni}-\mathrm{Mn}$ system and also with a single $\mathrm{e}^{(16)(17)}$ or simultaneous addition ${ }^{(18)}$ of $\mathrm{Cr}$ and $\mathrm{Mo}$ to the $\mathrm{Ni}$ $\mathrm{Mn}-\mathrm{Fe}$ system. In consequence, the highest value of

* This paper was presented at the Spring Meeting of the Japan Institute of Metals, March 30, 1969, Tokyo, Japan. The 45 th Report from The Foundation: The Research Institute of Electric and Magnetic Alloys, Sendai, Japan.

** The Foundation: The Research Institute of Electric and Magnetic Alloys, Sendai, Japan.

(1) H. Masumoto, T. Kobayashi and Y.Murakami : J. Japan Inst. Metals, 29 (1965), 228 ; Trans. JIM, 8 (1967), 49.

(2) H. Masumoto, T. Kobayashi and Y. Murakami : J. Japan Inst. Metals, 29 (1965), 1101; Trans. JIM, 8 (1967), 54.

(3) H. Masumoto, T. Kobayashi and Y.Murakami : J. Japan Inst. Metals, 30 (1966), 837; Trans. JIM, 8 (1967), 264.

(4) H. Masumoto, T.Kobayashi and Y. Murakami : J.Japan Inst. Metals, 31 (1967); Trans. JIM, 9 (1968), 355.

(5) H. Masumoto, T.Kobayashi and Y.Murakami : J.Japan Inst. Metals, 32 (1968), 521 ; Trans. JIM, 9 (1968), 355.

(6) H. Masumoto, Y. Murakami and M. Hinai : J. Japan Inst. Metals, 32 (1968), 444 ; Trans. JIM, 10 (1969), 115.

(7) H. Masumoto, Y. Murakami and M. Hinai : J. Japan Inst. Metals, 32 (1968), 856; Trans. JIM, 10.(1969), 247.

(8) H. Masumoto, Y. Murakami and M. Hinai : J. Japan Inst. Metals, 33 (1969), 130; Trans. JIM, 10 (1969), 247.

(9) H. Masumoto, Y. Murakami and M. Hinai : J. Japan Inst. Metals, 33 (1969), 235 ; Trans. JIM, 10 (1969), 414.

(10) H. Masumoto, Y. Murakami and M. Hinai : J. Japan Inst. Metals, 33 (1969), 488; Trans. JIM, 10 (1969), 414.

(11) H. Masumoto, Y. Murakami and M. Hinai : J. Japan Inst. Metals, 33 (1969), 1007.

(12) H. Masumoto, T. Kobayashi and Y. Murakami : J. Japan Inst. Metals, 33 (1969), 1141; Trans. JIM, 11 (1970), 166.
121000 in initial permeability and the highest value of 643000 in maximum permeability have been obtained in the $\mathrm{Ni}-\mathrm{Mn}-\mathrm{Fe}-\mathrm{Cr}-\mathrm{Mo}$ system. Masumoto et al. have further clarified from the measured data on some of these alloy systems that the saturation magnetostriction $\lambda_{s}{ }^{(19) \sim ~}$ (21) and the magnetic crystal anisotropy energy $K_{1}{ }^{(22)(23)}$ have very low values for the compositions at which high permeabilities are attained.

Among a series of experiments now in progress on the effect of various additive elements to the binary $\mathrm{Ni}-\mathrm{Mn}$ system, this paper describes the addition of $\mathrm{Ta}$ to $\mathrm{Ni}-\mathrm{Mn}$ alloys so as to investigate its effect on the characteristics of Nimalloy.

(13) H. Masumoto, Y. Murakami and M. Hinai : J. Japan Inst. Metals, $34(1970), 380$.

(14) H. Masumoto, Y. Murakami and M. Hinai : J. Japan Inst. Metals, 34 (1970), 40.

(15) H. Masumoto, Y. Murakami and M. Hinai : Presented at the Spring Meeting of the Japan Institute of Metals, Mar. 30, 1966, Tokyo, Japan.

(16) H. Masumoto, Y. Murakami and M. Hinai : Presented at the Autumn Meeting of the Japan Institute of Metals, Oct. 17, 1966, Amagasaki, Japan.

(17) H. Masumoto, Y. Murakami and M. Hinai : Presented at the Autumn Meeting of the Japan Institute of Metals, Oct. 1, 1967, Sapporo, Japan.

(18) Y. Murakami : Presented at the Autumn Meeting of the Japan Institute of Metals, Oct. 12, 1969, Hiroshima, Japan.

(19) H. Masumoto, T. Kobayashi and S. Kadowaki : Presented at the Autumn Meeting of the Japan Institute of Metals, Oct. 19, 1963, Nagoya, Japan.

(20) H. Masumoto, Y. Murakami and S. Kadowaki : Presented at the Autumn Meeting of the Japan Institute of Metals, Oct. 2, 1964, Toyama, Japan.

(21) H. Masumoto, Y. Murakami and S. Kadowaki : Presented at the Spring Meeting of the Japan Institute of Metals, Apr. 6, 1965, Tokyo, Japan.

(22) H. Masumoto, Y. Murakami and N. Nakamura : Presented at the Spring Meeting of the Japan Institute of Metals, Apr. 6, 1966, Tokyo, Japan.

(23) H. Masumoto, Y. Murakami and N. Nakamura : Presented at the Autumn Meeting of the Japan Institute of Metals, Oct. 17, 1966, Amagasaki, Japan.

1971 Vol. 12 


\section{Experimental Procedure}

The alloys used were prepared from electrolytic $\mathrm{Ni}$, electrolytic Mn and $99.97 \%$ pure Ta, of which the former two elements were of the same purities as reported in the preceding paper ${ }^{(1)}$. The preparation of specimens and measurements were similar to those described previously. The specimens used were fifty kinds of alloys with compositions of $71.68 \sim 93.52 \% \mathrm{Ni}, 3.80 \sim$ $22.56 \% \mathrm{Mn}$ and $2.08 \sim 14.83 \%$ Ta.

\section{Results and Discussion}

The experimental results are summarized in Figs. $1 \sim$ 10 and Table 1 . The specimens whose compositions are shown by the solid circles in Figs. $1 \sim 2$ were heated in vacuum at $900^{\circ} \mathrm{C}$ for $1 \mathrm{hr}$ and cooled to room temperature at nine different rates, $240^{\circ}, 100^{\circ}, 50^{\circ}, 20^{\circ}, 10^{\circ}$, $5^{\circ}, 3^{\circ}, 1.5^{\circ}$ and $0.75^{\circ} \mathrm{C} / \mathrm{hr}$. Depending on the compositions the specimen subjected to the similar heat treatment were cooled at $240^{\circ} \mathrm{C} / \mathrm{hr}$ and further baked at the specified temperatures below the order-disorder transformation point. The highest values of initial permeability $\mu_{0}$ and maximum permeability $\mu_{m}$ which were measured at room temperature with each of the ternary alloys are schematically represented in Figs. $1 \sim$ 2 by equi-value curves drawn statistically against composition. As shown in the figures, with the addition of $\mathrm{Ta}$ to $\mathrm{Ni}-\mathrm{Mn}$ alloys containing more than $10 \% \mathrm{Mn}$, $\mu_{0}$ and $\mu_{m}$ increase slowly at the beginning and then rapidly attain the highest values which subsequently decrease steeply and then gradually. The composition range corresponding to large values of $\mu_{0}$ and $\mu_{m}$ lies on the higher $\mathrm{Ni}$ side than the composition of $\mathrm{Ni}_{3}(\mathrm{Mn}, \mathrm{Ta})$. The highest values of $\mu_{0}$ and $\mu_{m}$ obtained on the ternary $\mathrm{Ni}-\mathrm{Mn}$-Ta system are 20470 in $\mu_{0}$ for the composition of $75.88 \% \mathrm{Ni}, 19.47 \% \mathrm{Mn}$ and $4.65 \% \mathrm{Ta}$ and 84800 in $\mu_{m}$ for the composition of $75.37 \% \mathrm{Ni}, 19.08 \% \mathrm{Mn}$ and $5.55 \% \mathrm{Ta}$. These values are considerably large as compared with 6860 in $\mu_{0}$ and 20400 in $\mu_{m}$ obtained with binary $\mathrm{Ni}-\mathrm{Mn}$ alloys.

Table 1 shows electrical and magnetic properties of the representative alloys in the ternary system, where $W_{h}$ is the magnetic hysteresis loss, $4 \pi I_{50}$ is the intrinsic magnetic induction in a field of $50 \mathrm{Oe}, \lambda_{s}$ is the saturation magnetostriction, and $\sigma$ is the electrical resistivity and $\alpha$ is its temperature coefficient. As shown in the table, the addition of $\mathrm{Ta}$ to the binary $\mathrm{Ni}-\mathrm{Mn}$ alloys achieves a marked improvement in magnetic performance

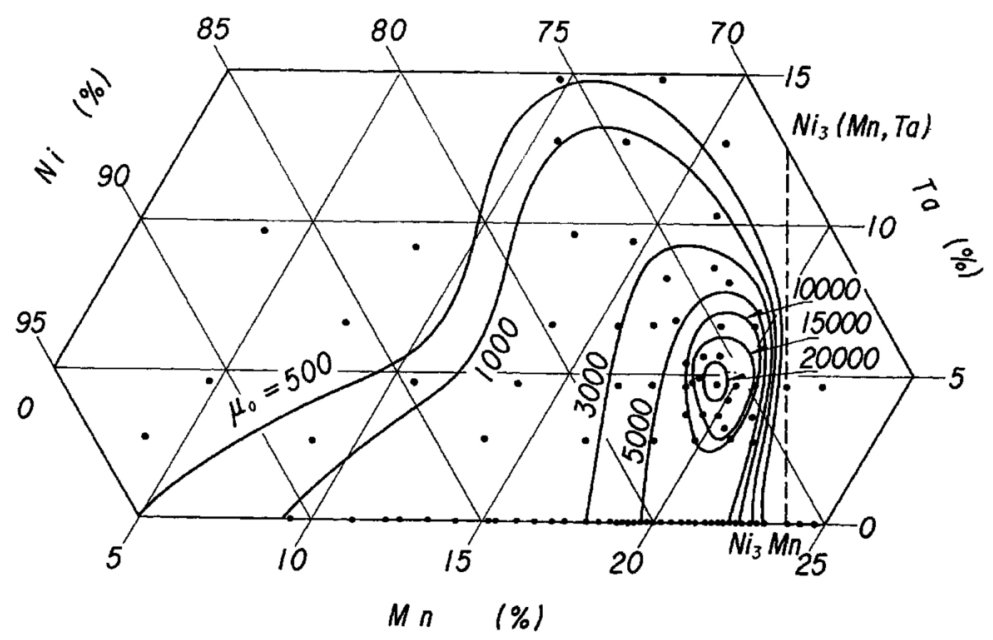

Fig. 1 Highest initial permeability in each of Ni-Mn-Ta alloys cooled at various rates from $900^{\circ} \mathrm{C}$ or further baked at various temperatures.

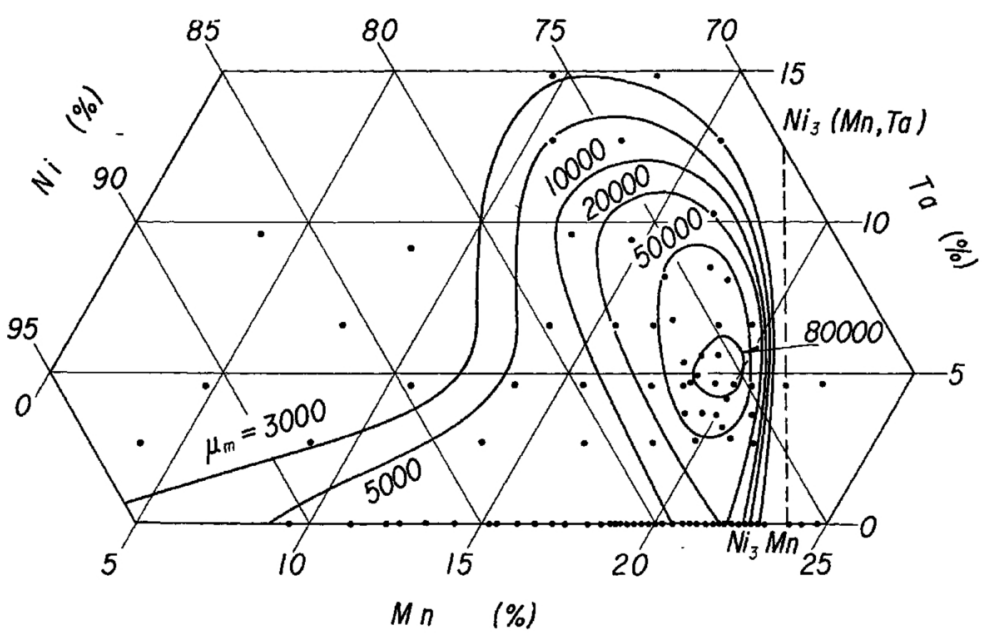

Fig. 2 Highest maximum permeability in each of $\mathrm{Ni}-\mathrm{Mn}$-Ta alloys cooled at various rates from $900^{\circ} \mathrm{C}$ or further baked at various temperatures. 
of Nimalloy, especially with notably increased values of $\mu_{0}, \mu_{m}$ and $4 \pi I_{50}$.

Figures $3 \sim 4$ show the curves for the dependence of $\mu_{0}$ and $\mu_{m}$ on Mn concentration and cooling rate for the ternary $\mathrm{Ni}-\mathrm{Mn}-\mathrm{Ta}$ alloys containing approximately 4.6 $\% \mathrm{Ta}$. The values of $\mu_{0}$ and $\mu_{m}$ indicate a marked variation with cooling rate in the composition range of $14.0 \sim 21.5 \% \mathrm{Mn}$. In the case of $\mu_{0}$, the curves show a first maximum in the low Mn concentration region and a second maximum in the high Mn concentration region, whereas only the second maximum is observed in the case of $\mu_{m}$. The second maxima for both $\mu_{0}$ and $\mu_{m}$ first increase with decrease in cooling rate, attaining 5040 in $\mu_{0}$ at $3^{\circ} \mathrm{C} / \mathrm{hr}$ for the composition of $19.47 \% \mathrm{Mn}$ and 58700 in $\mu_{m}$ at $5^{\circ} \mathrm{C} / \mathrm{hr}$ for the composition of $18.72 \% \mathrm{Mn}$ and then decrease. In the case of $\mu_{0}$, the positions of its first and second maxima shift toward smaller Mn contents with decreasing cooling rate. However, in the case of $\mu_{m}$, the position of its second maximum is very slightly changed.

Figure 5 shows the variations in $\mu_{0}$ and $\mu_{m}$ with changes in cooling rate for four kinds of the ternary alloys containing about $75.5 \% \mathrm{Ni}$. As can be seen from the figure, the cooling rate at which the highest value of permeability is attained becomes smaller with increasing Ta content, as evidenced by the fact that alloys No.30 and No.36 do not exhibit the highest permeability even at a very small rate such as $0.75^{\circ} \mathrm{C} / \mathrm{hr}$.

Table 1 Magnetic and electrical properties of typical Ni-Mn-Ta alloys

\begin{tabular}{|c|c|c|c|c|c|c|c|c|c|c|c|c|c|c|c|c|}
\hline \multirow{2}{*}{$\begin{array}{c}\text { Alloy } \\
\text { No. }\end{array}$} & \multirow{2}{*}{$\underset{(\%)}{\mathrm{Mn}}$} & \multirow{2}{*}{$\underset{(\%)}{\mathrm{Ta}}$} & \multirow{2}{*}{$\begin{array}{l}\text { Cooling } \\
\text { rate } \\
\text { from } \\
900^{\circ} \mathrm{C} \\
\left({ }^{\circ} \mathrm{C} / \mathrm{hr}\right)\end{array}$} & \multicolumn{2}{|c|}{ Baking } & \multirow{2}{*}{$\mu_{0}$} & \multirow{2}{*}{$\mu_{m}$} & \multirow{2}{*}{$\begin{array}{c}B(G) \\
\text { for } \\
\mu_{m}\end{array}$} & $\begin{array}{c}W_{h} \\
(\mathrm{erg} / \\
\mathrm{cm}^{3}\end{array}$ & $\begin{array}{l}\boldsymbol{B}_{\boldsymbol{r}} \\
(\mathbf{G})\end{array}$ & $\begin{array}{c}H_{c} \\
(\mathbf{O e})\end{array}$ & \multirow{2}{*}{$\begin{array}{c}4 \pi I_{50} \\
(G)\end{array}$} & \multirow{2}{*}{$\frac{\left(\begin{array}{c}\lambda_{s} \\
\left.\times 10^{-6}\right)\end{array}\right)}{\underset{9000 \mathrm{e}}{H=}}$} & \multirow{2}{*}{$\begin{array}{c}\sigma \\
(\mu \Omega- \\
\mathrm{cm}, \\
\left.20^{\circ} \mathrm{C}\right)\end{array}$} & \multirow{2}{*}{$\begin{array}{c}\alpha \\
\times 10^{-3}, \\
0^{\circ} \sim \\
\left.40^{\circ} \mathrm{C}\right)\end{array}$} & \multirow{2}{*}{$\begin{array}{l}\text { Density } \\
\left(\mathrm{g} / \mathrm{cm}^{3}\right)\end{array}$} \\
\hline & & & & $\begin{array}{l}\text { Tem- } \\
\text { perature } \\
\left({ }^{\circ} \mathrm{C}\right)\end{array}$ & $\underset{(\mathrm{hr})}{\mathrm{Time}}$ & & & & \multicolumn{3}{|c|}{$B_{m}=5000 \mathrm{G}$} & & & & & \\
\hline $\begin{array}{l}33 \\
35 \\
37\end{array}$ & $\begin{array}{l}21.63 \\
21.80 \\
22.00\end{array}$ & - & $\begin{array}{r}10 \\
5 \\
10\end{array}$ & $\frac{380}{380}$ & $\frac{50}{50}$ & $\begin{array}{l}6860 \\
5090 \\
5880\end{array}$ & $\begin{array}{l}18000 \\
12490 \\
20400\end{array}$ & $\begin{array}{l}891 \\
626 \\
908\end{array}$ & $\begin{array}{l}* 18.30 \\
* 18.50 \\
* 19.34\end{array}$ & $\begin{array}{r}* 951 \\
* 876 \\
* 1052\end{array}$ & $\begin{array}{l}* 0.0315 \\
* 0.0272 \\
* 0.0270\end{array}$ & $\begin{array}{l}* * 2790 \\
* * 2760 \\
* * 2804\end{array}$ & $\begin{array}{l}0 . \overline{17} \\
0.00\end{array}$ & $\begin{array}{l}60.7 \\
60.5 \\
60.7\end{array}$ & $\begin{array}{l}0.93 \\
0.94 \\
0.93\end{array}$ & $\begin{array}{c}\overline{8.42} \\
-\end{array}$ \\
\hline 6 & 19.83 & 2.77 & 20 & - & 一 & 3960 & 40300 & 1629 & $* 1806$ & $* 1757$ & $* 00941$ & 1170 & 000 & 690 & 105 & \\
\hline 6 & 19.83 & 2.77 & 240 & 380 & 30 & 10120 & 23700 & 640 & 10.80 & - & - & 2300 & 0. & 02.0 & 1.00 & 0.44 \\
\hline 9 & 19.08 & 3.63 & 50 & - & - & 2200 & 57800 & 1657 & - & - & - & 3875 & - & - & - & - \\
\hline 12 & 20.43 & 3.18 & 240 & 460 & 23 & 5280 & 58800 & 1968 & 65.62 & 3120 & 0.0309 & 5225 & 0.17 & 60.7 & 1.02 & 8.46 \\
\hline 12 & 20.43 & 3.18 & 24.0 & 460 & 46 & 16280 & 394,00 & 1697 & 48.10 & 2180 & 0.0331 & 5780 & 0.00 & 57.5 & 1.71 & - \\
\hline 20 & 18.72 & 4.66 & 240 & 400 & 90 & 1870 & 67000 & 1923 & - & - & 二 & 4910 & 0.17 & 60.5 & 1.51 & - \\
\hline 21 & 18.83 & 4.86 & 5 & - & - & 1760 & 58100 & 2550 & 67.35 & 3230 & 0.0320 & 6340 & - & - & - & 8.49 \\
\hline 21 & 18.83 & 4.86 & 240 & 4,40 & 10 & 2300 & 81600 & 1577 & - & - & - & 4870 & - & - & - & - \\
\hline 21 & 18.83 & 4.86 & 240 & 440 & 86 & 19350 & 42700 & 2450 & 33.04 & 1272 & 0.0249 & 64,20 & -0.17 & 48.6 & 1.45 & - \\
\hline 22 & 19.47 & 4.65 & 3 & - & - & 5040 & 48400 & 2794 & - & - & - & - & & 54.7 & 1.28 & 8.50 \\
\hline 22 & 19.47 & 4.65 & 240 & 440 & 70 & 12540 & 80200 & 2980 & 47.67 & 3579 & 0.0289 & 6660 & -1.70 & 51.2 & 1.26 & - \\
\hline 22 & 19.47 & 4.65 & 240 & 460 & 64 & 20470 & 55200 & 3170 & 53.65 & 2670 & 0.0330 & 6580 & - & 50.3 & 1.32 & - \\
\hline 23 & 20.07 & 4.10 & 240 & 460 & 48 & 17390 & 33100 & 1885 & 46.40 & 2594 & 0.0327 & 5770 & 0.17 & 40.1 & 1.28 & - \\
\hline 24 & 20.09 & 4.58 & 240 & 460 & 35 & 16280 & 81900 & 2741 & 40.83 & 3710 & 0.0242 & 6580 & 0.00 & 56.4 & 1.16 & - \\
\hline 30 & 19.08 & 5.55 & 24,0 & 440 & 65 & 8360 & 84800 & 2375 & 50.85 & 4325 & 0.0253 & 6805 & 0.00 & 52.7 & 1.10 & 8.49 \\
\hline 30 & 19.08 & 5.55 & 24,0 & 440 & 75 & 17280 & 74900 & 2508 & 57.30 & 4295 & 0.0259 & 7060 & - & 45.3 & 1.22 & - \\
\hline 35 & 17.15 & 6.75 & 240 & 460 & 100 & 2750 & 59500 & 2564 & 77.50 & 4535 & 0.0372 & 6770 & 一 & 50.3 & 1.16 & - \\
\hline 36 & 18.60 & 6.55 & 240 & 400 & 440 & 4180 & 76200 & 2186 & 63.55 & 4740 & 0.0334 & 7295 & 0.00 & 53.9 & 1.25 & 8.65 \\
\hline 36 & 18.60 & 6.55 & 240 & 400 & 580 & 11000 & $54,4,00$ & 2600 & 60.40 & 3677 & 0.0387 & 7375 & 0.00 & 45.5 & 1.19 & - \\
\hline 39 & 17.38 & 8.46 & 240 & 440 & 240 & 1430 & 54,450 & 2865 & 62.74 & 3540 & 0.0376 & 6560 & - & 58.2 & 1.14 & 8.73 \\
\hline 40 & 18.11 & 8.05 & 240 & 400 & 540 & 2420 & 50203 & 2640 & 96.22 & 4611 & 0.0480 & 6815 & - & 50.4 & 1.08 & - \\
\hline 44 & 14.65 & 9.38 & 2800 & 440 & 10 & 880 & 38500 & 1844 & - & - & - & 4050 & - & - & - & 8.89 \\
\hline
\end{tabular}

${ }^{*} B_{m}=2000 \mathrm{G}, \quad{ }^{* * *} \mathrm{H}=9000 \mathrm{e}$

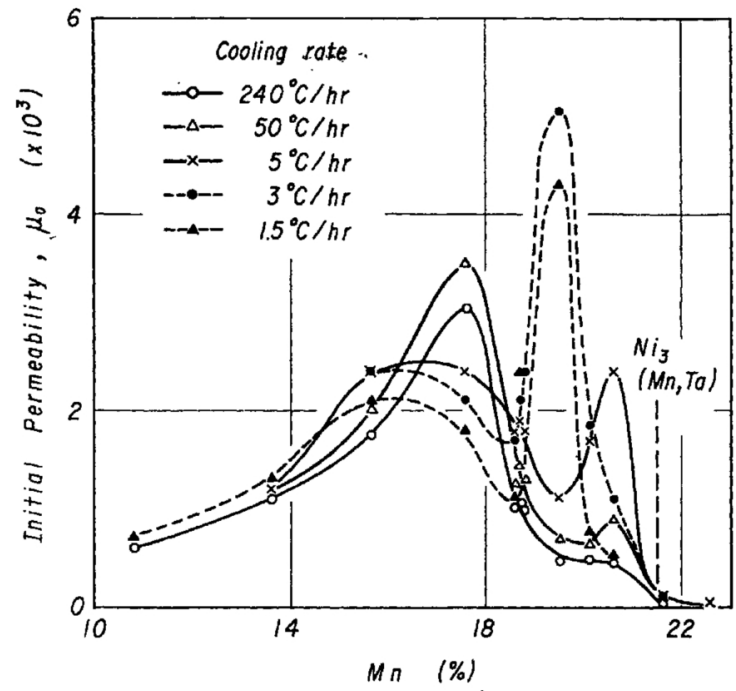

Fig. 3 Initial permeability of $\mathrm{Ni}-\mathrm{Mn}-$ about $4.6 \% \mathrm{Ta}$ alloys cooled at various rates from $900^{\circ} \mathrm{C}$.

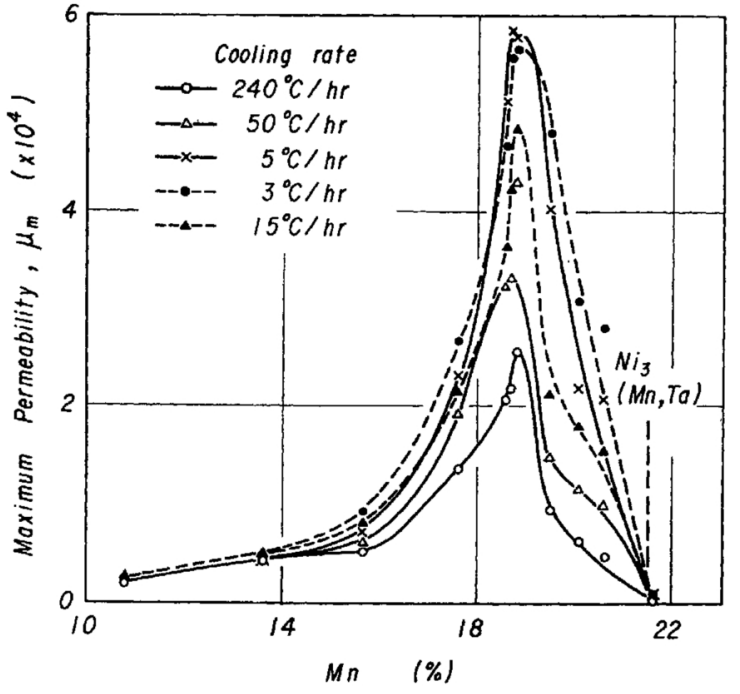

Fig. 4 Maximum permeability of $\mathrm{Ni}-\mathrm{Mn}$ - about $4.6 \% \mathrm{Ta}$ alloys cooled at various rates from $900^{\circ} \mathrm{C}$. 
Accordingly, as a condition essential to develop the highest level of permeability, the ternary alloys should be further baked at temperatures below the orderdisorder transformation point in a way to advance the degree of order.

Figure 6 illustrates the relationship between the bake time and the values of $\mu_{0}$ and $\mu_{m}$ when the same $\mathrm{Ni}$ $\mathrm{Mn}-\mathrm{Ta}$ alloys as in Fig. 5 were cooled from $900^{\circ} \mathrm{C}$ to room temperature at $240^{\circ} \mathrm{C} / \mathrm{hr}$ and further baked at $440^{\circ} \mathrm{C}$. In general the permeability has a maximum

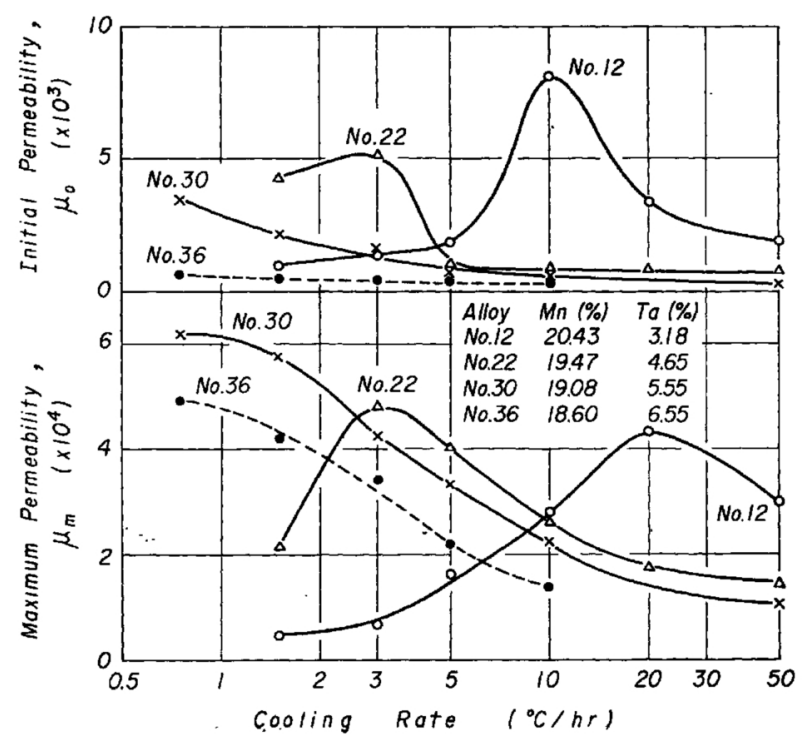

Fig. 5 Effect of cooling rate on initial and maximum permeabilities of $\mathrm{Ni}-\mathrm{Mn}$-Ta alloys containing about $75.5 \% \mathrm{Ni}$.

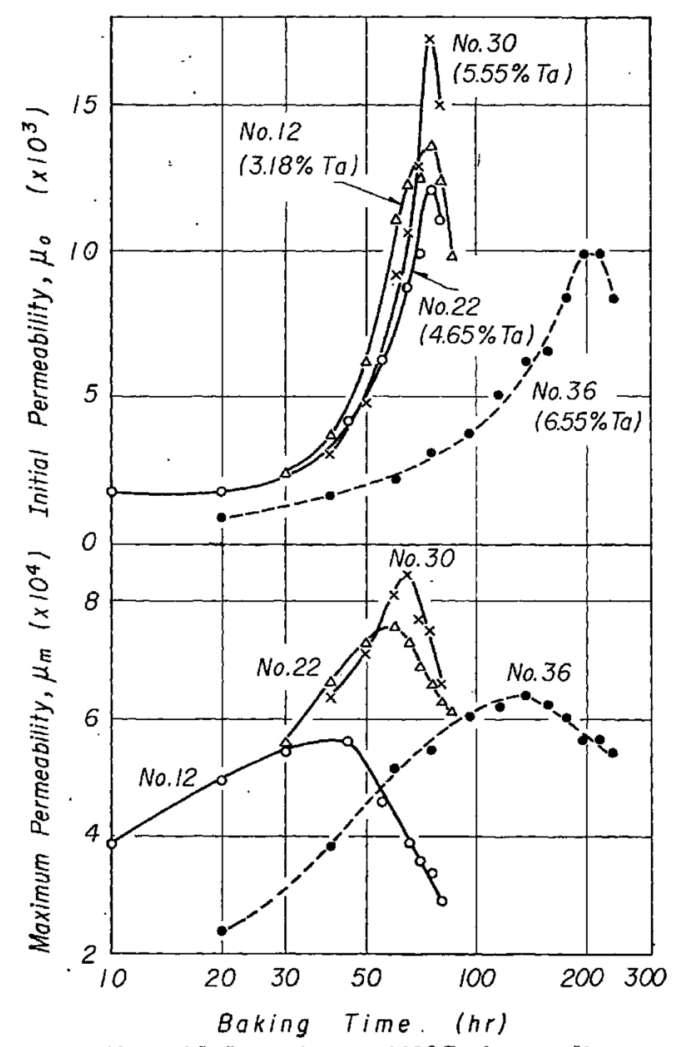

Fig. 6 Effect of baking time at $440^{\circ} \mathrm{C}$ after cooling at a rate of $240^{\circ} \mathrm{C} / \mathrm{hr}$ from $900^{\circ} \mathrm{C}$ on initial and maximum permeabilities of $\mathrm{Ni}-\mathrm{Mn}-\mathrm{Ta}$ alloys containùng about $75.5 \% \mathrm{Ni}$. against baking time, and its maximum shifts toward a longer baking time with increase in Ta content.

Figure 7 shows the variations in $\mu_{0}$ and $\mu_{m}$ with baking time for alloy No. $30(75.37 \% \mathrm{Ni}, 19.08 \% \mathrm{Mn}$ and $5.55 \% \mathrm{Ta}$ ) with the highest value of $\mu_{m}$ in the Ni$\mathrm{Mn}-\mathrm{Ta}$ system which was baked at various temperatures after cooling from $900^{\circ} \mathrm{C}$ to room temperature at 240 ${ }^{\circ} \mathrm{C} / \mathrm{hr}$. All the curves in the figure indicate a maximum which appears at a shorter baking time with increase in baking temperature. This implies that the rate of

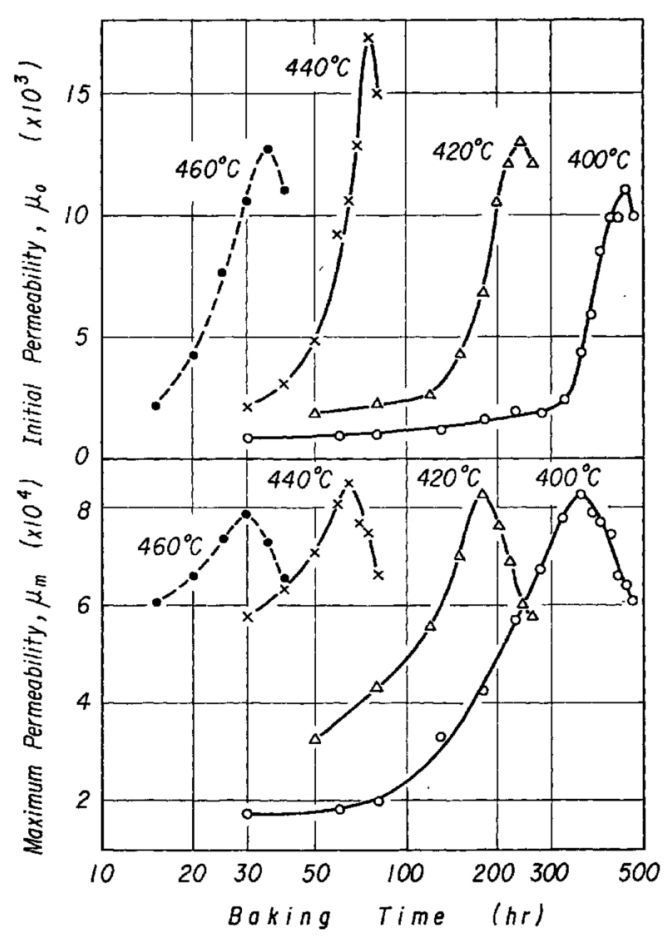

Fig. 7 Effect of baking temperature and time after cooling at a rate of $240^{\circ} \mathrm{C} / \mathrm{hr}$ from $900^{\circ} \mathrm{C}$ on initial and maximum permeabilities of No. 30 alloy $(75.37 \% \mathrm{Ni}-19.08 \% \mathrm{Mn}-5.55 \% \mathrm{Ta})$.

superlattice structure formation becomes faster with the rise in baking temperature. Regardless of the baking temperature, the maximum of $\mu_{m}$ appears at a shorter baking time than in the case of the maximum of $\mu_{0}$. The highest value of $\mu_{0}$ is 17280 when baked at $440^{\circ} \mathrm{C}$ for $75 \mathrm{hr}$ and the highest value of $\mu_{m}$ is 84800 when baked at the same temperature for $65 \mathrm{hr}$. It will be noted that although a high level of permeability can be obtained with the ternary compositions near to about $5 \% \mathrm{Ta}$ by slow cooling from $900^{\circ} \mathrm{C}$, the highest permeability can be achieved with the compositions of more than $5 \% \mathrm{Ta}$ by baking at temperatures below the orderdisorder transformation point for an appropriate baking time.

Figures 8 and 9 illustrate the composition dependence of $4 \pi I_{50}$ and $\sigma$ at $20^{\circ} \mathrm{C}$ for each of the Ni-Mn-Ta alloys which were subjected to heat treatment to develop the highest maximum permeability. In general the ternary alloys which exhibit a high permeability at compositions near to about $74 \sim 78 \% \mathrm{Ni}$ are considered in an advanced rate of ordering in view of the fact that their values are relatively large in $4 \pi I_{50}$ and somewhat low in $\sigma$. In Fig. 10 are shown the magnetization and 


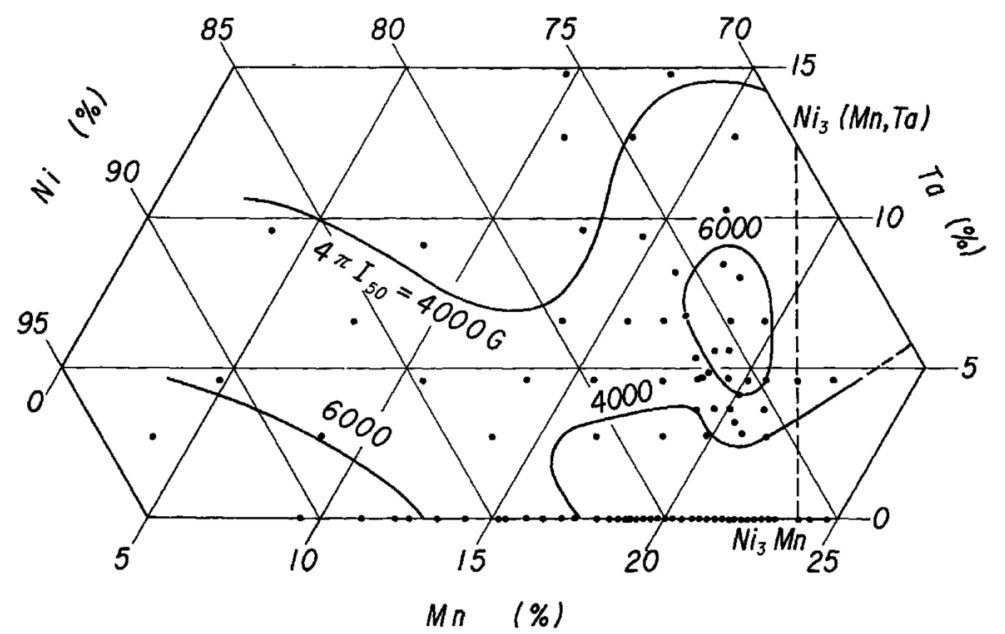

Fig. 8 Intrinsic magnetic induction at a magnetic field of $500 \mathrm{e}$ in $\mathrm{Ni}-\mathrm{Mn}-\mathrm{Ta}$ alloys heat-treated to develop the highest maximum permeability.

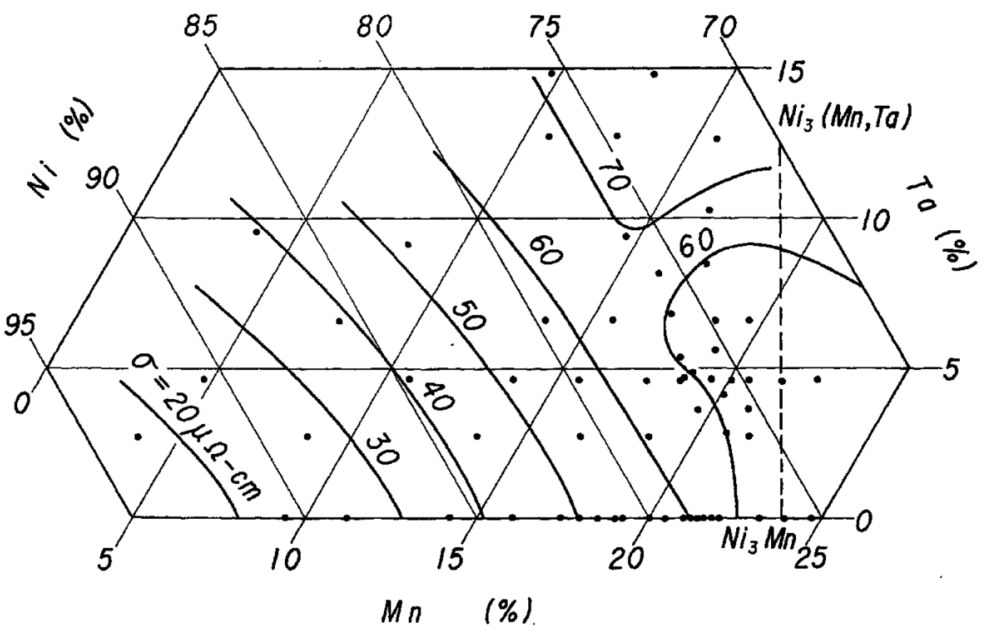

Fig. 9 Electrical resistivity at $20^{\circ} \mathrm{C}$ in $\mathrm{Ni}-\mathrm{Mn}$-Ta alloys heat-treated to develop the highest maximum permeability.

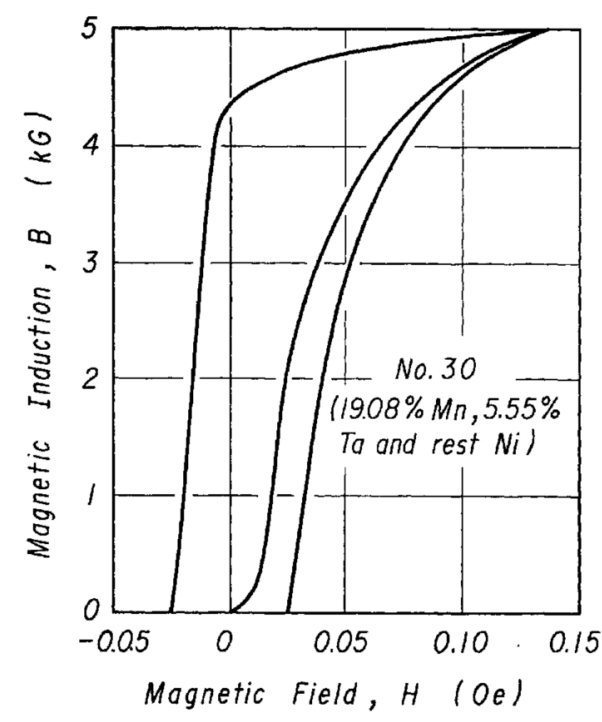

Fig. 10 Magnetization and hysteresis curves of No. 30 alloy baked at $440^{\circ} \mathrm{C}$ for $65 \mathrm{hr}$ after cooling at a rate of $240^{\circ} \mathrm{C} / \mathrm{hr}$ from $900^{\circ} \mathrm{C}$.

hysteresis curves for alloy No. 30 with the highest value of $\mu_{m}$ in the $\mathrm{Ni}-\mathrm{Mn}-\mathrm{Ta}$ system when baked at $440^{\circ} \mathrm{C}$ for $65 \mathrm{hr}$ after cooling from $900^{\circ} \mathrm{C}$ to room temperature at $240^{\circ} \mathrm{C} / \mathrm{hr}$. From these curves it is evident that the alloy has excellent magnetic properties.

As high-permeability alloys have been known to be characterized by a very low value of saturation magnetostriction, high permeabilities are shown in the alloys of the $\mathrm{Ni}-\mathrm{Mn}-\mathrm{Ta}$ system which have low values of magnetostriction as shown in Table 1.

\section{Conclusions}

The magnetic properties, electrical resistivity and temperature coefficient of resistivity at room temperature were measured on fifty kinds of ferromagnetic NiMn-Ta alloy, with composition of $71.68 \sim 93.52 \% \mathrm{Ni}$, $3.80 \sim 22.56 \% \mathrm{Mn}$ and $2.68 \sim 14.83 \% \mathrm{Ta}$. The alloys measured were those heated in vacuum at $900^{\circ} \mathrm{C}$ for $1 \mathrm{hr}$ and then cooled at various rates or further baked at various temperatures below the order- disorder transformation point after cooling at $240^{\circ} \mathrm{C} / \mathrm{hr}$. The results obtained are as follows :

(1) The highest values of initial permeability and maximum permeability obtained on each of $\mathrm{Ni}-\mathrm{Mn}-\mathrm{Ta}$ alloys increase gradually at the beginning and later rapidly with increasing Ta content, and after attaining a maximun, the values decrease gradually. The highest 
value of initial permeability is 20470 for the composition of $75.88 \% \mathrm{Ni}, 19.47 \% \mathrm{Mn}$ and $4.65 \% \mathrm{Ta}$ when baked at $460^{\circ} \mathrm{C}$ for $64 \mathrm{hr}$ after cooling from $900^{\circ} \mathrm{C}$ to room temperature at $240^{\circ} \mathrm{C} / \mathrm{hr}$, and the highest value of maximum permeability is 84800 for the composition of $75.37 \% \mathrm{Ni}, 19.08 \% \mathrm{Mn}$ and $5.55 \% \mathrm{Ta}$ when baked at $440^{\circ} \mathrm{C}$ for $65 \mathrm{hr}$ after cooling from $900^{\circ} \mathrm{C}$ at 240 ${ }^{\circ} \mathrm{C} / \mathrm{hr}$.

(2) The coercivity for the maximum magnetic induction of $5000 \mathrm{G}$ shows a low value in general. The lowest value is 0.02420 e for the composition of $75.33 \% \mathrm{Ni}$,
$20.09 \% \mathrm{Mn}$ and $4.58 \% \mathrm{Ta}$, the corresponding hysteresis loss being $40.83 \mathrm{erg} / \mathrm{cm}^{3} /$ cycle.

(3) The intrinsic magnetic induction in an effective field of $50 \mathrm{Oe}$ is relatively large. The alloy composed of $75.37 \% \mathrm{Ni}, 19.08 \% \mathrm{Mn}$ and $5.55 \% \mathrm{Ta}$ which exhibits the highest maximum permeability in the ternary system shows the magnetic induction of $6805 \mathrm{G}$ and the electrical resistivity of $52.7 \mu \Omega-\mathrm{cm}$ at $20^{\circ} \mathrm{C}$.

(5) At room and high temperatures, these $\mathrm{Ni}-\mathrm{Mn}-\mathrm{Ta}$ alloys can more easily be forged and rolled than Permalloy. 